\title{
ASSESSMENT OF THE ENVIRONMENTAL PURIFICATION OF TRIANGLE SAIL MUSSEL (HYRIOPSIS CUMINGII) IN RECIRCULATING AQUACULTURE SYSTEMS
}

\author{
YU, X. B. ${ }^{1,2,3}-$ ZHAO, Z. ${ }^{1,3}-$ TANG, R. ${ }^{1,3}-$ XIONG, B. ${ }^{1,2,3}-$ WU, Z. L. ${ }^{1,2,3}-$ SU, S. Q. ${ }^{1,2,3}-$ \\ YAO, W. Z. ${ }^{1,2,3^{*}}$ \\ ${ }^{1}$ College of Animal Science and Technology, Southwest University, Chongqing, China \\ (First author e-mail: yuxiaobo6@126.com) \\ ${ }^{2}$ Comprehensive Experimental Station of Chongqing, National Shellfish Industry Technology \\ System, China \\ ${ }^{3}$ Research Center of Fishery Resources and Environment, Southwest University, Chongqing, \\ China \\ Corresponding author \\ e-mail: yaowz@swu.edu.cn \\ (Received $13^{\text {th }}$ Nov 2019; accepted $12^{\text {th }}$ Mar 2020)
}

\begin{abstract}
The current study was undertaken to assess the environmental adaptability and water capability of Hyriopsis cumingii in a recirculating aquaculture system in the Chongqing region, Southwestern China. A total of 175 species of planktonic algae belonging to 8 phylum and 75 genera were found at all sampling sites. $66.3 \%-80.0 \%$ of them belong to the Chlorophyta and Bacillariophyta phyla, the main food sources of bivalve shellfish. The annual investigation results show that the range of water physical and chemical indexes fully meets the requirements of $H$. cumingii growth, with its average wet weight increasing from $359.4 \mathrm{~g}$ to $525.6 \mathrm{~g}$. Concerning water purification, even though $H$. cumingii had no obvious effect on the composition of planktonic algae, it could reduce the phytoplankton biomass in all five sampling sites in the summer by $23.7 \%$ on average. Moreover, the transparency of the ecological purification area can be increased by $15.3 \%$ on average. Besides, the decrease of electro conductivity (4.9\%), ammonia nitrogen $(6.7 \%)$ and phosphate $(7.2 \%)$ in $H$. cumingii purification area was determined in this study. Overall, $H$. cumingii showed excellent ecological purification function, and its mixed farming model based on the recirculating aquaculture system is worthy of further study.
\end{abstract}

Keywords: Hyriopsis cumingii, recirculating aquaculture system, phytoplankton, ecological purification, freshwater

\section{Introduction}

Human beings have complex social and ecological dependency on the freshwater ecosystem (Kingsford et al., 2011; Horton et al., 2015). In recent years, the environmental function of freshwater shellfish has gradually attracted the attention of the industry due to the policy guidance in China. Some mixed breeding modes, such as "fish and mussel mixed breeding" and "shellfish and shrimp mixed breeding", have been mentioned and developed again in freshwater aquaculture (Modesto et al., 2018; Wang et al., 2018). However, freshwater shellfish industry has been neglected for a long time in China due to its small scale and long economic cycle. The production of 0.20 million tons only accounts for $0.66 \%$ of the total freshwater aquaculture in 2018 (Zhang et al., 2019). Moreover, the freshwater shellfish industry is still in the infancy in southwest China, and its adaptability to the local environment and related water purification mechanisms need to be studied urgently. This project mainly focuses on the growth adaptation and water 
purification function of Hyriopsis cumingii in the recirculating aquaculture system in the Chongqing region.

Recirculating aquaculture system (RAS) is a water circulation pond with an air stripping device to realize high-density intensive aquaculture in a rectangular mixed-cell rearing unit (Watten et al., 2000; Ebeling et al., 2005). It has transparent functional partitions including the aquaculture area, tail water discharge area and purification area. This mode has been applied and extended in the Chongqing region in recent years. Our group predicts that $\mathrm{N}, \mathrm{P}$ and phytoplankton are abundant in the tail water discharge area, and potential water purification could be achieved by cultivating shellfish. On one hand, shellfishes may provide an ecosystem service through nutrient assimilation in soft tissues and adamant shells, and facilitate the permanent removal of carbon, nitrogen, phosphorus, bacteriological quality and so on (Cha et al., 2011; Kellogg et al., 2013; Bianchi et al., 2014). Meanwhile, the purification function and physiological responses of shellfish may be expected to vary with environmental conditions (Bianchi et al., 2014; Hoellein et al., 2015). On the other hand, phytoplanktons are primary producers in pond aquaculture, and their species, quantity, community structure and species diversity have significant influence on the growth of aquatic animals (Daines et al., 2014). Previous studies have suggested that freshwater shellfish can effectively control the content of chlorophyll and organic matter in ponds (Hawkins et al., 2013). Besides, bivalves show specific feeding selectivity in the process of filter feeding. For example, the digestibility of greenshell mussel Perna canaliculus to dinoflagellates is higher than that of diatoms, showing a carnivorous tendency (Ren et al., 2006). However, the studies remain unknown on phytoplankton growth and reproduction, diversity index and stability of the pond ecosystem.

China's commercial freshwater pearl industry has been developing for more than 50 years and has accounted for more than $90 \%$ of the world's total cultured pearl production in recent two decades (Dan and Ruobo, 2002). Among them, as a unique Unionidae family resource in China, bivalve mollusk triangle sail mussel $H$. cumingii is the best selection for producing high quality freshwater pearls and is widely distributed in the Yangtze River basin and Huaihe River basin (Jin et al., 2012; Qu et al., 2018). At present, despite the great development in the research of artificial propagation and seedling raising (Li and Li, 2009), genetic breeding (Bai et al., 2016), growth traits and pearl cultivation (Jin et al., 2019; Zhang et al., 2019), the applied research on the ecological function still lags in $H$. cumingii. Recently, the use of $H$. cumingii has been proposed as an alternative measure to control algal bloom in eutrophic water bodies (Liu et al., 2014). However, there is no comprehensive data on the dynamic response mechanism of phytoplankton and its correlation with water quality factors. Besides, the water environment in southwest China meets the requirements of $H$. cumingii farming in theory. The optimal conditions for $H$. cumingii growth mainly include water temperature $\left(23-32^{\circ} \mathrm{C}\right)$, dissolved oxygen $(\mathrm{DO},>4 \mathrm{mg} / \mathrm{L}), \mathrm{pH}(>7.5)$ and salinity $(<0.2 \%$ ), total alkalinity $(24-219 \mathrm{mg} / \mathrm{L})$, total hardness $(40-218 \mathrm{mg} / \mathrm{L})$, total nitrogen $(\mathrm{TN}, 0.52-1.91 \mathrm{mg} / \mathrm{L})$ and total phosphorus $(\mathrm{TP}$, 0.06-0.30 mg/L), etc. (Lin et al., 2004). Also, the growth of bivalve shellfish could be effected by the species of shellfish, the nutrition of the bait, the season changes and mixed culture mode (Naddafi et al., 2007). The aim of the present study was to comprehensively investigate the purification function of $H$. cumingii in a recirculating aquaculture system, including the influence on algal facies and water quality factors. 


\section{Methods}

\section{Sampling site and $\mathrm{H}$. cumingii layout}

In 2018, we first set up five recirculating aquaculture system testing bases in the Chongqing region, southwest China (Figure 1A), including Tongliang qinggang breeding bases $\left(29^{\circ} 8449^{\prime} \mathrm{N}, 105^{\circ} 8609^{\prime} \mathrm{E}\right)$, Bishan xinyue aquaculture co., LTD $\left(29^{\circ} 6844^{\prime} \mathrm{N}\right.$, $\left.106^{\circ} 2537^{\prime} \mathrm{E}\right)$, Bishan zhubi breeding base $\left(29^{\circ} 6853^{\prime} \mathrm{N}, 106^{\circ} 2559^{\prime} \mathrm{E}\right)$, Changshou dahonghu aquatic co., LTD $\left(30^{\circ} 0406^{\prime} \mathrm{N}, 106^{\circ} 9742^{\prime} \mathrm{E}\right)$ and Liang ping hongyun fishery co., $\operatorname{LTD}\left(30^{\circ} 6791^{\prime} \mathrm{N}, 107^{\circ} 6472^{\prime} \mathrm{E}\right)$. Each flume is about $7 \mathrm{~m}$ in length and $2.5 \mathrm{~m}$ in width. Healthy H. cumingii (Wet weight: $368.9 \pm 106.1 \mathrm{~g}$, Shell length: $15.7 \pm 1.4 \mathrm{~cm}$; Shell width: $4.2 \pm 0.3 \mathrm{~cm}$; Shell height: $12.5 \pm 1.2 \mathrm{~cm}$ ) aged about 3 years were located about $30 \mathrm{~cm}$ underwater in the outlet area of the aquaculture pond (Figure 1B). Furthermore, the average amount of $H$. cumingii in the purification area is 400-600 per aquaculture pond. The water quality and algal facies of the shellfish purification area, tail water discharge area and ecological purification area were monitored for four quarters on March 21, June 20, September 3 and December 25. Sampling sites Bishan zubi were not fully sampled because the $H$. cumingii were not stocking in spring and the florfenicol induced shellfish death in winter.

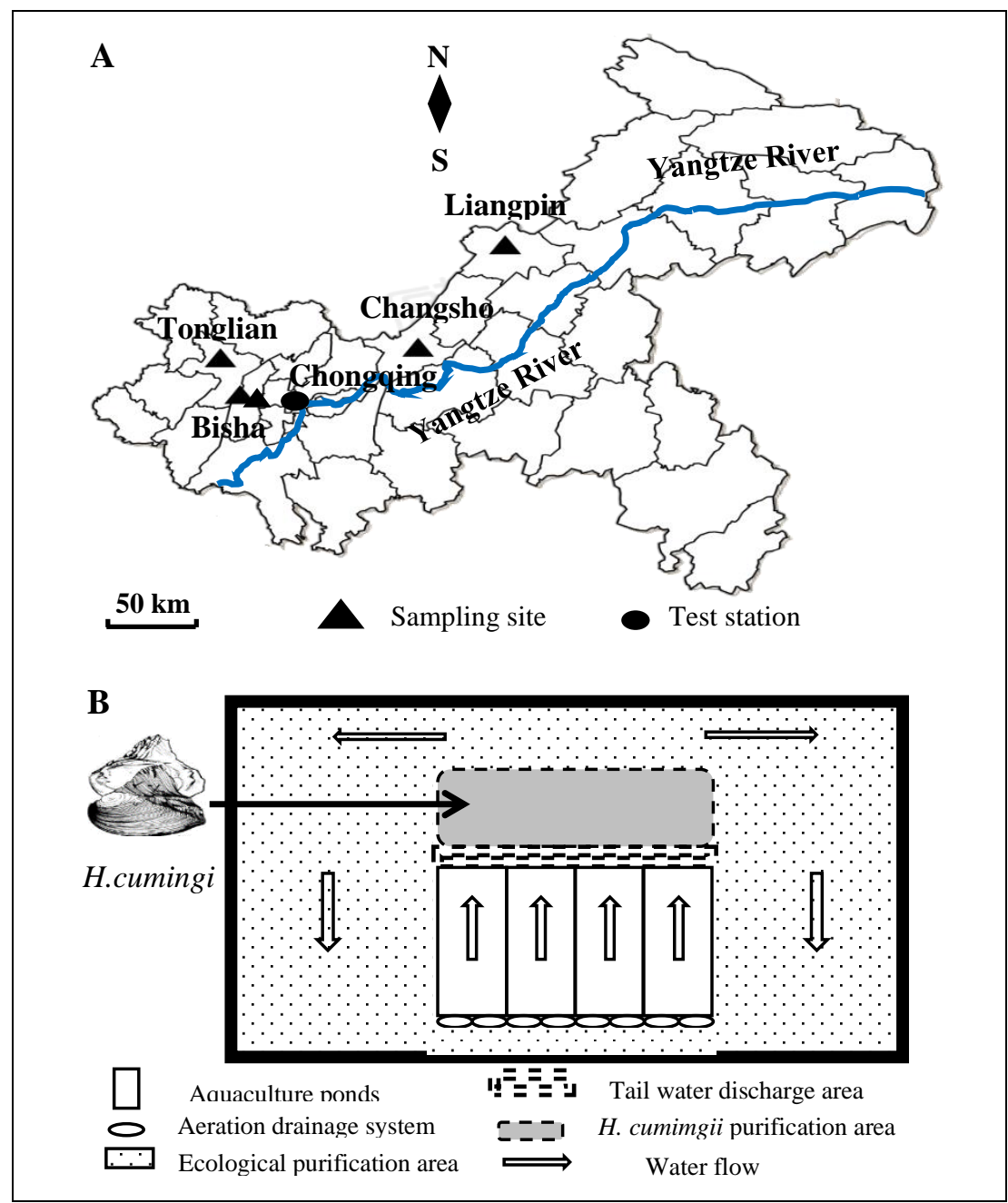

Figure 1. Testing bases distribution for recirculating aquaculture system in the Chongqing region $(A)$ and the schematic diagram of Hyriopsis cumingii aquaculture area selection $(B)$ 


\section{Phytoplankton quantitative collection}

The collection of water samples from different sampling points and functional areas was accomplished according to the established methods in hydrobiology. Mixed water samples of about $0.5 \mathrm{~m}$ depth were collected with plexiglass water sampler, then fixed with $1.5 \%$ Lugol's iodine, placed in sedimentator for $24 \mathrm{~h}$ and concentrated into $50 \mathrm{~mL}$ centrifuge tube. Treated samples were qualitatively and quantitatively analysed by microscope counting. The phytoplankton composition of samples was determined by referring to "The common phytoplankton atlas of Chongqing region of the three gorges reservoir area" and "The common freshwater phytoplankton algae atlas of China" (Zhou and Zheng, 2005; Weng and $\mathrm{Xu}, 2010$ ). The quantitative formula of phytoplankton is as follow:

$$
\mathrm{C}=N \times \frac{S_{c}}{S_{f} \times n} \times \frac{V_{1}}{V_{2} \times V}
$$

where, $C$ is the phytoplankton density; $N$ is the count result of phytoplankton in the observation field; $S_{c}$ is the area of the counting box; $S_{f}$ is the area per view; $\mathrm{n}$ is the number of views per slice; $V_{1}$ is the volume after concentration; $V_{2}$ is the volume of the counting box; $V$ is the volume before concentration.

The calculation formula of preponderance degree is as follow:

$$
\mathrm{Y}=\frac{n_{i}}{N} \times f_{i}
$$

where, $Y$ is the preponderance degree; $f_{i}$ is the frequency of algae $i$ in the sample; $n_{i}$ is the density of algae $\mathrm{i} ; N$ is the total algal density. Among them, the dominant species is algae with $\mathrm{Y}$ value greater than 0.02 , and the absolute dominant species is algae with $\mathrm{Y}$ value greater than 0.1 .

\section{Investigation in the physical and chemical index of water bodies}

Electro conductivity, dissolved oxygen (DO) and $\mathrm{pH}$ values were detected by the portable dissolved oxygen meter (HQ30D, HACH Company, USA). Water temperature and transparency were detected by the water thermometer and transparency disc, respectively. Moreover, water samples were collected and brought back to the laboratory for water quality analysis according to relevant national standards (Wei et al., 2002). The collection, fixation and preservation of water samples were conducted following "the code for water environment monitoring (SL219-98, in Chinese)". Ammonia nitrogen was measured by the Nessler reagent colorimetry $\left(\mathrm{NH}_{4}{ }^{+}-\mathrm{N}, \mathrm{GB}\right.$ 7479-87). The phosphomolybdic acid methodologies measured phosphate ( $\left.\mathrm{PO}_{4}{ }^{3-}-\mathrm{P}, \mathrm{GB} 9727-2007\right)$.

\section{Statistical processing}

Electro conductivity, water temperature, dissolved oxygen and $\mathrm{pH}$ values were measured twice with a calibrated portable dissolved oxygen meter. Each phytoplankton parameter and waterquality index was determined twice independently. All data expressed as mean. 


\section{Results}

\section{Phytoplankton composition and structure in sampling sites}

A total of 175 species of planktonic algae belonging to 8 phyla and 75 genera were found in all five sampling sites (Figure 2A). Among them, Chlorophyta had the highest number of 33 genera and 67 species, accounting for $44.0 \%$ and $39.4 \%$ of the total. The second to the eighth are Bacillariophyta (16 genera, 45 species), Cyanophyta (13 genera, 24 species), Euglenophyta (5 genera, 21 species), Pyrrophyta (2 genera, 5 species), Cryptophyta ( 2 genera, 4 species), Xanthophyta (2 genera, 2 species) and Chrysophyta (2 genera, 2 species) phyla, respectively. Moreover, although the number of algae is different in each sampling site, the composition of algae facies is roughly consistent with the overall structure (Figure $2 B$ ). Moreover, the total number of species of Chlorophyta, Bacillariophyta, Cyanophyta and Euglenophyta phyla at all sampling sites were accounted for more than $90 \%$. Among them, Chlorophyta and Bacillariophyta phyla are important bait categories of shellfish, accounting for $68.5 \%, 80.0 \%, 70.8 \%, 67.1 \%$ and $66.3 \%$ of the sampling sites respectively (Figure $2 B$ ). Also, there was a great difference in species classification among the sampling points. Fifty-five of the 175 species, or 32.4 percent, were observed at only one sampling site. And about half of the algae species were detected at only one or two sampling sites. Only $23.5 \%$ of the species were detected at all five sampling sites (Figure $2 C$ ).

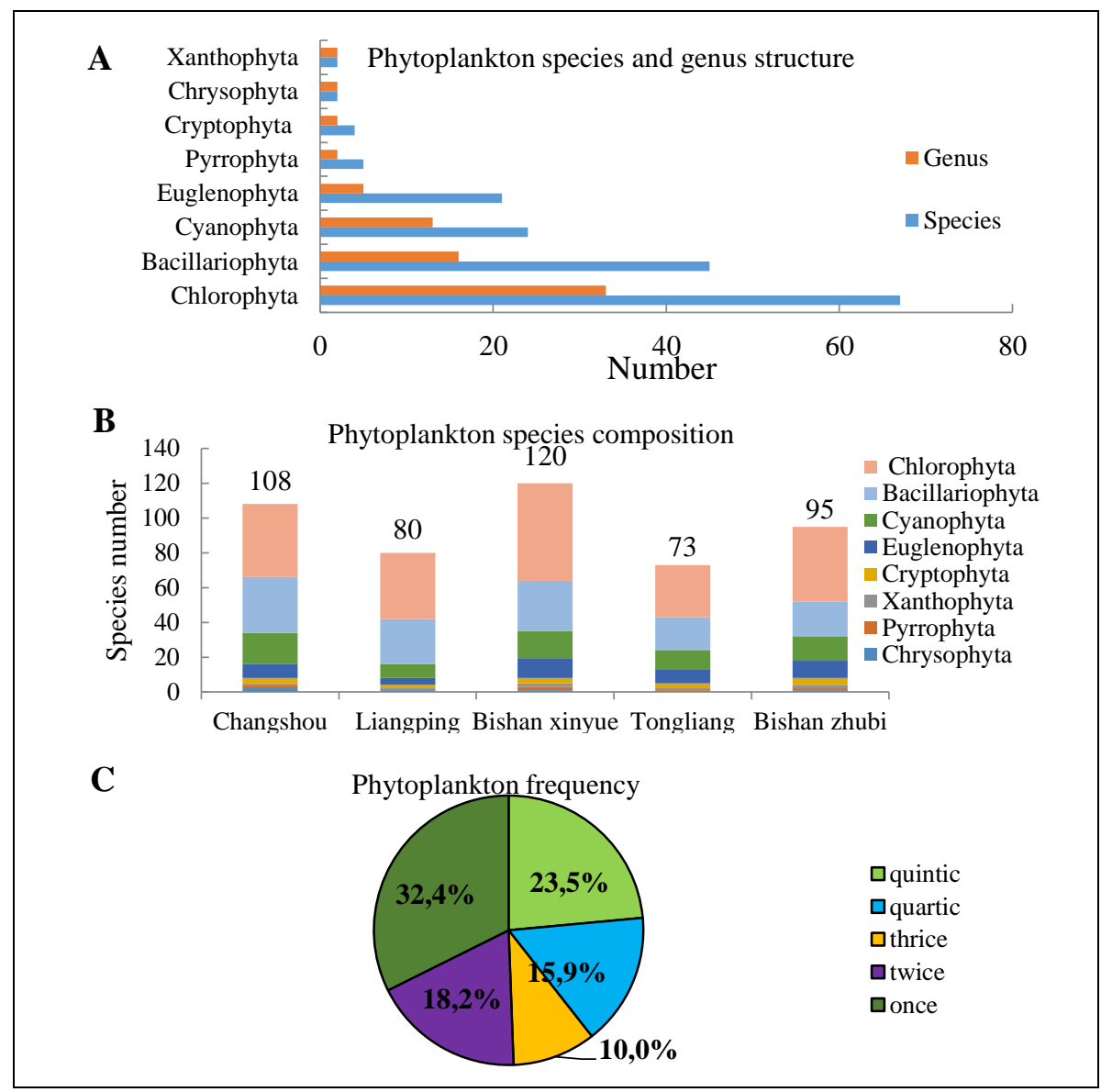

Figure 2. Distribution of phytoplankton. (A) shows the species and genus structure in all sampling sites. $(B)$ shows the phytoplankton species composition in each sampling sites. $(C)$ shows the distribution characteristics of phytoplankton between sampling sites 


\section{Filtering effect of $\mathrm{H}$. cumingii on phytoplankton}

H. cumingii filtering effects on phytoplankton were reflected in Figure 3. The results indicated that the phytoplankton biomass in summer and autumn were higher than those of spring and winter in Changshou, Liangping and Bishan xinyue. Sampling sites Bishan zubi were not fully sampled because the $H$. cumingii were not stocking in spring and the florfenicol induced shellfish death in winter. The results also revealed that $H$. cumingii could effectively reduce the biomass of phytoplankton. The phytoplankton biomass of the shellfish purification area and biological purification area were generally lower than that of the tail water discharge area. Results showed a $23.7 \%$ biomass reduction on average in all five samplings sites in the summer. Among them, the Liangping biomass of shellfish purification area and ecological purification has fallen by more than $85 \%$ in comparison with tail water discharge area in the summer. Besides, in some parts of the sampling sites phytoplankton biomass showed no noticeable change, such as Bishan zubi in winter, Changshou, Liangping and Tongliang in autumn (Figure 3A-D).

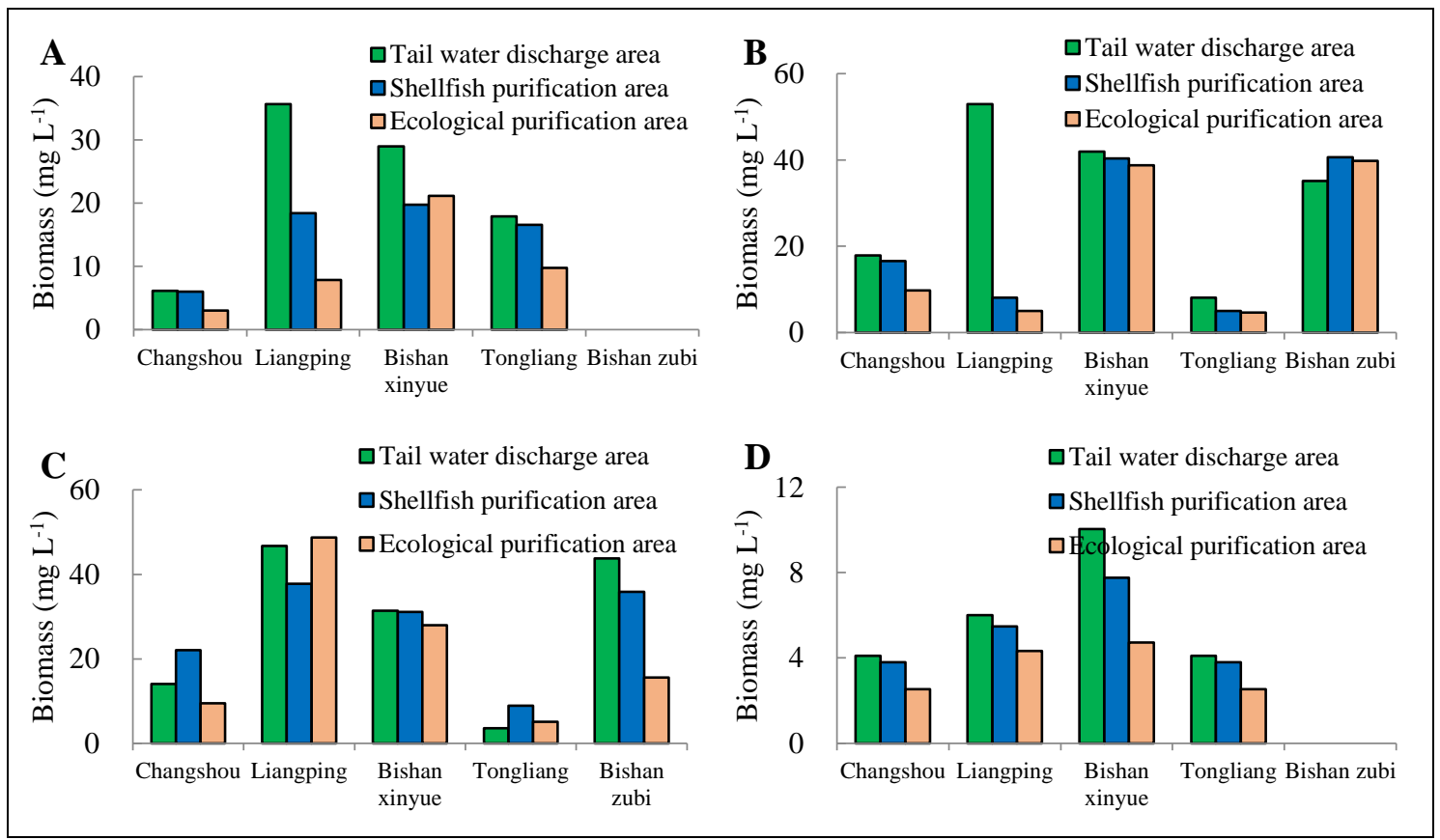

Figure 3. Filtering effect of $H$. cumingii on phytoplankton biomass in four seasons (A, Spring; B, Summer; C, Autumn; D, winter)

Although $H$. cumingii can significantly reduce the phytoplankton biomass, the total number of dominant algae has no obvious change. The preponderance degree and dominant species analysis results of higher biomass in summer and autumn are shown in Tables 1 and 2, respectively. Phytoplankton's dominant species mainly belong to the Cyanophyta, Chlorophyte and Bacillariophyta phyla in each sampling site. And a few numbers of dominant species mainly belong to the Xanthophyta, Euglenophyta and Cryptophyta phyla. However, the summer preponderance degree of all the Chlorophyte and Bacillariophyta in Bishan zubi, Tongliang and Bishan xinyue are less than 0.02, except Chlorella vulgaris Beij and Coelastrum microporum Nägeli (Table 1). The autumn preponderance degree of all the Chlorophyte and Bacillariophyta phyla in Changshou are less than 0.02, except Pandorina morum Bory and Synedra acusvar (Table 2). 
Table 1. Phytoplankton dominant species and preponderance degree in summer $(Y>0.02)$

\begin{tabular}{|c|c|c|c|c|c|c|c|c|c|c|c|c|c|c|c|}
\hline \multirow{2}{*}{ Phytoplankton } & \multicolumn{3}{|c|}{ Changshou } & \multicolumn{3}{|c|}{ Liangping } & \multicolumn{3}{|c|}{ Bishan zubi } & \multicolumn{3}{|c|}{ Tongliang } & \multicolumn{3}{|c|}{ Bishan xinyue } \\
\hline & $\mathrm{T}$ & $\mathrm{H}$ & $\mathrm{E}$ & $\mathrm{T}$ & $\mathrm{H}$ & $\mathrm{E}$ & $\mathrm{T}$ & $\mathrm{H}$ & $\mathrm{E}$ & $\mathrm{T}$ & $\mathrm{H}$ & $\mathrm{E}$ & $\mathrm{T}$ & $\mathrm{H}$ & $\mathrm{E}$ \\
\hline Cyanophyta & & & & & & & & & & & & & & & \\
\hline Nostoc communes vauch. & & & 0.054 & & & & & & & & & & & & \\
\hline Merismopedia eleggans $\mathrm{Br}$. & & 0.041 & & & 0.023 & & 0.394 & 0.423 & 0.286 & 0.021 & & & & 0.070 & 0.060 \\
\hline Merismopedia punctata Meyen & 0.303 & 0.265 & 0.122 & & & & & & & & & & 0.100 & & \\
\hline Phormidium tenue (Menegh.) Gom. & 0.118 & 0.102 & 0.078 & & & & 0.023 & 0.030 & 0.026 & 0.022 & 0.025 & & 0.180 & 0.160 & 0.090 \\
\hline Coelosphaerium dubium Grunow & & & & & & & 0.387 & 0.352 & 0.411 & 0.865 & 0.876 & 0.845 & 0.390 & 0.440 & 0.560 \\
\hline Chroococcus minor (Kütz.) Näg. & 0.091 & 0.073 & 0.074 & & & & & & & & & & & & \\
\hline Chroococcus minutus (Kütz.) Näg. & & & & & & 0.034 & & & & & & & & & \\
\hline Anabaenopsis arnoldii Aptek. & 0.113 & 0.136 & 0.132 & & & & & & & & & & & & \\
\hline Microcystis flos-aquae (Wittr.) Kirchn. & 0.317 & 0.051 & 0.083 & & & & & & & & & & & & \\
\hline Anabaena sphaerica & & & & & & 0.065 & & & & & & & & & \\
\hline Microcystis incerta Lemm. & 0.047 & 0.075 & 0.044 & & & & & & & & & & & & \\
\hline Chlorophyta & & & & & & & & & & & & & & & \\
\hline Sceaedesmus dimorphus (Turp.) Kütz. & & & & 0.034 & & 0.029 & & & & & & & & & \\
\hline Sceaedesmus quadricauda (Turp.) Bréb. & & 0.049 & 0.034 & & 0.077 & & & & & & & & & & \\
\hline Coelastrum microporum Nägeli & & & & & & & 0.022 & & & & & & & & \\
\hline Planktosphaeria gelatinosa G.M.Smith & & & & 0.030 & 0.050 & & & & & & & & & & \\
\hline Crucigenia tetrapedia (Kirch.) Morr. & & & 0.026 & 0.042 & & & & & & & & & & & \\
\hline Crucigenia puadrata Morren & & & & 0.038 & 0.104 & & & & & & & & & & \\
\hline
\end{tabular}




\begin{tabular}{|c|c|c|c|c|c|c|c|c|c|c|c|c|c|c|c|}
\hline \multirow{2}{*}{ Phytoplankton } & \multicolumn{3}{|c|}{ Changshou } & \multicolumn{3}{|c|}{ Liangping } & \multicolumn{3}{|c|}{ Bishan zubi } & \multicolumn{3}{|c|}{ Tongliang } & \multicolumn{3}{|c|}{ Bishan xinyue } \\
\hline & $\mathrm{T}$ & $\mathrm{H}$ & $\mathrm{E}$ & $\mathrm{T}$ & $\mathrm{H}$ & $\mathrm{E}$ & $\mathrm{T}$ & $\mathrm{H}$ & E & $\mathrm{T}$ & $\mathrm{H}$ & E & $\mathrm{T}$ & $\mathrm{H}$ & $\mathrm{E}$ \\
\hline Selenastrum bibraianum Reinsch & & & & & 0.073 & & & & & & & & & & \\
\hline Chlorella vulgaris Beij. & & & & 0.380 & 0.276 & 0.079 & 0.120 & 0.091 & 0.085 & 0.038 & 0.028 & 0.028 & 0.160 & 0.120 & 0.100 \\
\hline Chlamydomonas globosa Snow & & & & & 0.132 & & & & & & & & & & \\
\hline Tetraspora & & & 0.027 & & & 0.025 & & & & & & & & & \\
\hline Cosmarium formosulum Hoff. & & & & & 0.033 & & & & & & & & & & \\
\hline Bacillariophyta & & & & & & & & & & & & & & & \\
\hline Asterionella formosa. & & & & & & 0.150 & & & & & & & & & \\
\hline Synedra amphicephala Kützing. & & & & & 0.048 & & & & & & & & & & \\
\hline Cymatopleura stelligera Grun. & & & & 0.186 & 0.029 & & & & & & & & & & \\
\hline Melosira granulata (Ehr.) Ralfs & & & & & & 0.432 & & & & & & & & & \\
\hline Cocconeis placentula (Ehr.) Hust. & & & & 0.046 & & & & & & & & & & & \\
\hline Gyrosigma acuminatum (Kütz.) Rabenhor & & & & & & & & & & & & & & & \\
\hline Diatoma vulgure Borg. & & & & 0.051 & & & & & & & & & & & \\
\hline Fragilaria capucina Desm. & & & & & & 0.021 & & & & & & & & & \\
\hline Nitzschia longissima (Breb.) Ralfs & & & & & & & & & & & & & & & \\
\hline Xanthophyta & & & & & & & & & & & & & & & \\
\hline Monallantus brevicylindrus Pasch. & & & & 0.076 & 0.061 & & & & & & & & & & \\
\hline Species number & 6 & 8 & 10 & 10 & 11 & 8 & 5 & 4 & 4 & 4 & 3 & 2 & 4 & 4 & 4 \\
\hline
\end{tabular}

$\mathrm{T}$ represents tail water discharge area, $\mathrm{H}$ represents $\mathrm{H}$. cumingii purification area, E represents ecological purification area 
Table 2. Phytoplankton dominant species and preponderance degree in autumn $(Y>0.02)$

\begin{tabular}{|c|c|c|c|c|c|c|c|c|c|c|c|c|c|c|c|}
\hline \multirow{2}{*}{ Phytoplankton } & \multicolumn{3}{|c|}{ Changshou } & \multicolumn{3}{|c|}{ Liangping } & \multicolumn{3}{|c|}{ Bishan zubi } & \multicolumn{3}{|c|}{ Tongliang } & \multicolumn{3}{|c|}{ Bishan xinyue } \\
\hline & $\mathrm{T}$ & $\mathrm{H}$ & $\mathrm{E}$ & $\mathrm{T}$ & $\mathrm{H}$ & $\mathrm{E}$ & $\mathrm{T}$ & $\mathrm{H}$ & $\mathrm{E}$ & $\mathrm{T}$ & $\mathrm{H}$ & $\mathrm{E}$ & $\mathrm{T}$ & $\mathrm{H}$ & $\mathrm{E}$ \\
\hline Cyanophyta & & & & & & & & & & & & & & & \\
\hline Merismopedia eleggans $\mathrm{Br}$. & & & & & & & & & 0.048 & & & & & & \\
\hline Merismopedia punctata Meyen & 0.352 & 0.288 & 0.267 & 0.619 & 0.599 & 0.598 & 0.135 & 0.392 & 0.248 & 0.650 & 0.553 & 0.229 & 0.280 & 0.270 & 0.220 \\
\hline Oscillatoria tenuis Ag. & & & & & & & & & & & 0.027 & 0.062 & & & \\
\hline Oscillatoria princeps Vauch. & & & & & & & & & & & & & & & 0.030 \\
\hline Phormidium tenue (Menegh.) Gom. & & & & 0.022 & & 0.022 & & & & & 0.077 & 0.098 & & & \\
\hline Coelosphaerium dubium Grunow & 0.429 & 0.075 & 0.376 & & & & & & & & & & & & \\
\hline Aphanizomenon flos-aquae & & 0.040 & 0.072 & & & & & & & & & & & & \\
\hline Aphanocapsa pulchra & & 0.326 & & & & & & & & & & & & & \\
\hline Chroococcus minor (Kütz.) Näg. & & & & & & & 0.066 & 0.113 & 0.134 & & 0.058 & 0.067 & 0.060 & 0.030 & 0.030 \\
\hline Anabaenopsis sp. & 0.120 & 0.174 & 0.140 & & & & & & & & 0.049 & 0.345 & & & \\
\hline Anabaena osicellarioides Bory. & & 0.031 & 0.034 & & & & & & & & & & & & \\
\hline Chlorophyta & & & & & & & & & & & & & & & \\
\hline Sceaedesmus cavinaus (Lemm.) Chod. & & & & & & & & 0.037 & & & & & & & \\
\hline Sceaedesmus dimorphus (Turp.) Kütz. & & & & & 0.037 & & & & & 0.062 & 0.055 & 0.025 & 0.080 & 0.060 & \\
\hline Sceaedesmus quadricauda (Turp.) Bréb. & & & & & & & & 0.072 & 0.082 & 0.049 & & 0.021 & 0.090 & 0.090 & \\
\hline Sceaedesmus perforatus Lemm. & & & & & & & 0.045 & & & & & & & & \\
\hline Coelastrum sp. & & & & & & & & & 0.034 & & & & 0.200 & 0.050 & \\
\hline Staurastrum gracile Ralfs & & & & & & & 0.022 & & & & & & & & \\
\hline Cosmarium & & & & & & & & & 0.023 & & & & & & \\
\hline Ankistrodesmus sp. & & & & & & & & & 0.061 & & & & & & \\
\hline Cosmarium laeve & & & & & & & 0.097 & & & & & & & & \\
\hline Tetrastrum staurogeniaeforme Schr. & & & & & & & 0.038 & & & & & & & & \\
\hline Sphaerocystis schroeteri Chodat & & & & & & & & & & 0.041 & & & & & \\
\hline Planktosphaeria gelatinosa G.M.Smith & & & & & & & 0.022 & & & & & 0.044 & 0.050 & 0.040 & 0.030 \\
\hline Crucigenia tetrapedia (Kirch.) Morr. & & & & & 0.023 & & & 0.036 & 0.030 & & & & 0.090 & 0.110 & \\
\hline
\end{tabular}




\begin{tabular}{|c|c|c|c|c|c|c|c|c|c|c|c|c|c|c|c|}
\hline \multirow{2}{*}{ Phytoplankton } & \multicolumn{3}{|c|}{ Changshou } & \multicolumn{3}{|c|}{ Liangping } & \multicolumn{3}{|c|}{ Bishan zubi } & \multicolumn{3}{|c|}{ Tongliang } & \multicolumn{3}{|c|}{ Bishan xinyue } \\
\hline & $\mathrm{T}$ & $\mathrm{H}$ & E & $\mathrm{T}$ & $\mathrm{H}$ & $\mathrm{E}$ & $\mathrm{T}$ & $\mathrm{H}$ & $\mathrm{E}$ & $\mathrm{T}$ & $\mathrm{H}$ & $\mathrm{E}$ & $\mathrm{T}$ & $\mathrm{H}$ & $\mathrm{E}$ \\
\hline Crucigenia puadrata Morren & & & & & & & & & & & & & & & 0.090 \\
\hline Tetraspora lacustris Emm & & & & & & & & & & & & & & 0.040 & \\
\hline Chlorella vulgaris Beij. & & & & 0.187 & 0.154 & 0.189 & 0.199 & & & 0.086 & 0.042 & & 0.250 & & \\
\hline Chlamydomonas globosa Snow & & & & & & & & 0.020 & 0.030 & & & & & & \\
\hline Chlamydomonas microsphaera Pasch & & & & & & 0.026 & & & & & & & & & \\
\hline Pandorina morum Bory. & 0.049 & 0.048 & 0.067 & & & & & 0.088 & & & & & & & \\
\hline Tetraspora & & & & & & & 0.027 & & 0.041 & & & & & & \\
\hline Bacillariophyta & & & & & & & & & & & & & & & \\
\hline Synedra ulna Ehrenberg & & & & & & & 0.026 & & & & & & & & \\
\hline Synedra acusvar & & & 0.029 & & & & & & 0.039 & & & & & & \\
\hline Navicula simplex Krassk. & & & & & & & & & 0.032 & & & & & & \\
\hline Cymatopleura stelligera Grun. & & & & & & & & & & 0.032 & & & & & \\
\hline Navicula viridula Kütz. & & & & & & & 0.021 & & & 0.049 & 0.031 & & & & \\
\hline Xanthophyta & & & & & & & & & & & & & & & \\
\hline Monallantus brevicylindrus Pasch. & & & & & & & 0.066 & & & & & & & & \\
\hline Euglenophyta & & & & & & & & & & & & & & & \\
\hline Trachelomonas oblonga Lemm. & & & & & & & 0.026 & & & & & & & & \\
\hline Cryptophyta & & & & & & & & & & & & & & & \\
\hline Cryptomonas ovata Ehr. & & & & & & & 0.065 & 0.026 & 0.025 & & & & & & \\
\hline Cryptomonas rostrata & & & & & & & & 0.038 & 0.033 & & & & & & \\
\hline Species number & 4 & 7 & 7 & 3 & 4 & 4 & 14 & 9 & 14 & 7 & 8 & 8 & 8 & 8 & 5 \\
\hline
\end{tabular}

$\mathrm{T}$ represents tail water discharge area, $\mathrm{H}$ represents $\mathrm{H}$. cumingii purification area, E represents ecological purification area 
Furtherly, phytoplankton dominant species in all sampling sites changed constitutively with the turn of seasons. For example, the dominant algae in Liangping mainly belong to Bacillariophyta and Chlorophyte phyla in the summer, and change into Cyanophyta phyla in autumn. Overall, $H$. cumingii showed an excellent filter-feeding feature to Chlorella vulgaris Beij, Sceaedesmus dimorphus Kütz, Merismopedia punctata Meyen, Cymatopleura stelligera Grun and Navicula viridula Kütz, as the preponderance degree of the shellfish purification area and ecological purification area are lower than that of the tail water discharge area (Tables 1 and 2).

\section{Effects of $H$. cumingii on water environmental characteristics}

The basic physical and chemical characteristics of the aquaculture water in the testing base are shown in Figure 4. The change of water temperature is basically consistent among five testing bases. Among them, Changshou base autumn water temperature can reach $35.6^{\circ} \mathrm{C}$, and the temperature at the Liangping base is as low as $9.2^{\circ} \mathrm{C}$ in winter. The results showed that $H$. cumingii adapted to the changes in water temperature in the Chongqing region (Figure 4A). The dissolved oxygen at different sampling sites and seasons varied greatly, but all the concentration was within the range of $4-12 \mathrm{mg} \mathrm{L}^{-1}$ (Figure 4B). Moreover, the water quality of the pond was weakly alkaline at all sampling sites, except Changshou in autumn and winter and Bishan in autumn (Figure 4C). Overall, the water environment in the Chongqing region fully meets the requirements of H. cumingii farming.
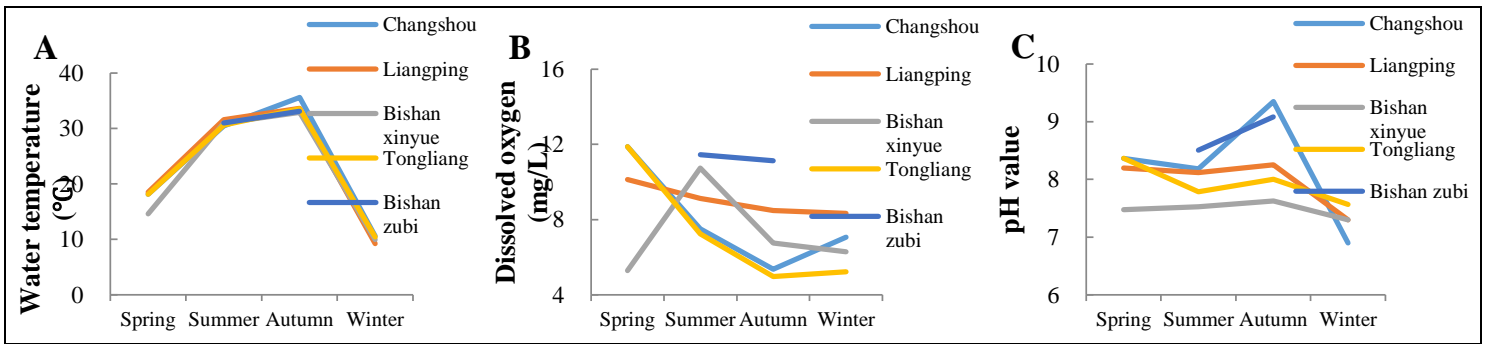

Figure 4. Basic environmental factor of the aquaculture water in samplings sites. (A, water temperature; $B$, dissolve oxygen; $C, p H$ value)

The water purification effects of $H$. cumingii were reflected in Figure 5. The water transparency, electric conductivity, ammonia nitrogen and phosphate at different sampling sites and seasons are significantly different (Figure 5A-D). And the electro conductivity $(4.9 \%)$, ammonia nitrogen $(6.7 \%)$ and phosphate $(7.2 \%)$ in purification area also decreased in this study. Besides, the results showed that the water transparency of spring and winter were higher than those of summer and autumn in each sampling sites. Generally, $H$. cumingii exhibited certain improvement effect on water transparency (Figure 5A). Conversely, the electro conductivity in spring and winter were lower than those in summer and autumn. However, the electro conductivity of the shellfish purification area and ecological purification area generally are equal to or lower than that of the tail water discharge area in sampling sites, except Tongliang and Bishan zubi in the summer (Figure 5B). The decrease of ammonia nitrogen and phosphate in the H. cumingii purification area has appeared only in part of sampling sites, such as Changshou, Liangping and Bishan xinyue (Figure 5C-D). To some extent, H. cumingii has improved water quality in inner circulation ponds. 


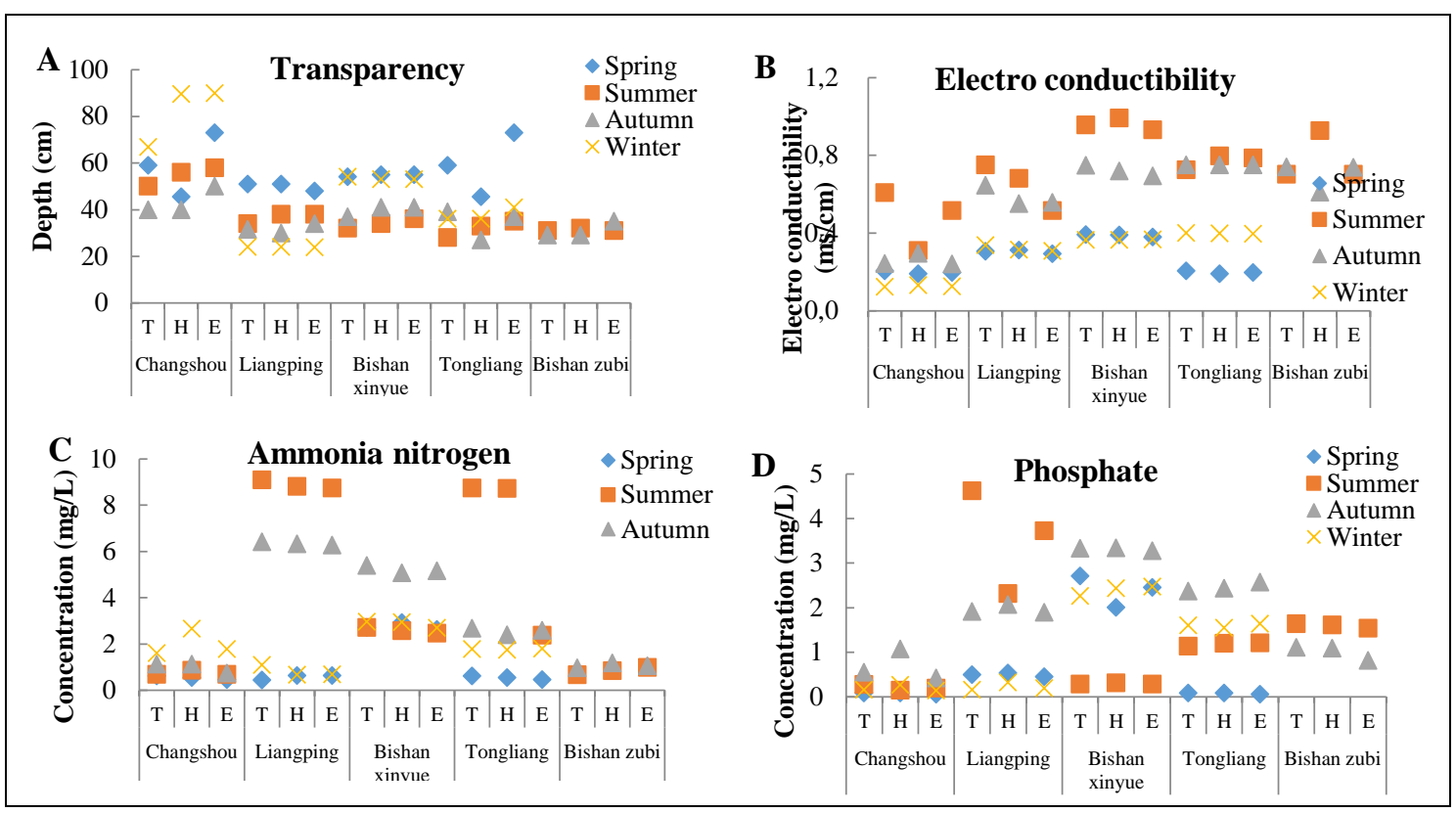

Figure 5. Purifying effect of $H$. cumingii on transparency (A), electro conductivity (B), ammonia nitrogen $(C)$ and phosphate $(D)$. Where letter " $T$ " represents tail water discharge area, " $H$ " represents $H$. cumingii purification area and " $E$ " represents ecological purification area

\section{Discussion}

Southeast Asia has proved to be a global hotspot for freshwater mussel diversity due to the existence of 228 native and 3 non-native Bivalvia: Unionida (98\% Unionidae, 2\% Margaritiferidae). In this region, species richness was the highest in China (particularly Yangtze River basin) in absolute numbers and Cambodia when correcting for the country area, and decreased gradually towards the surrounding area (Zieritz et al., 2018). However, freshwater shellfish industry is still in its infancy in upper-middle reaches of the Yangtze River, especially in Chongqing, Sichuan, Guizhou and Yunnan provinces in southwest China, where the production of bivalve shellfish accounts for less than $0.04 \%$ of the total freshwater aquaculture in 2018 (Zhang et al., 2019). The newly established Chongqing Comprehensive Experimental Station, as the only freshwater comprehensive experimental station in the non-main producing areas, is mainly responsible for studying the ecological service function and fishery economic value of shellfish, and promoting the healthy development of freshwater shellfish industry in southwest China and even in wider regions. The present annual investigation results confirm that the water quality fully meets the requirements of $H$. cumingii growth in the Chongqing region (Lin et al., 2004; Liu et al., 2020). The average wet weight increased from $359.4 \mathrm{~g}$ to $525.6 \mathrm{~g}$ within 2018 in the five sampling sites. This investigation can be used as the basis for further development of shellfish industry in southwest China.

Automated closed recirculating aquaculture system, namely partitioned aquaculture system, was early designed in the United States (Brune et al., 2001). In recent years, this mode has been widely used in Zhejiang, Jiangsu and Chongqing regions in China. The renewed interest in recirculating aquaculture systems is also due to their perceived advantages, including significantly reduced water requirements, a high degree of environmental control, improved waste management, promoted nutrient recycling and so 
on (Martins et al., 2010). Moreover, this water circulation system can realize high-density intensive aquaculture in rectangular mixed-cell rearing unit (Ebeling et al., 2005) and has clear functional partitions including aquaculture area, tail water discharge area and purification area. Our group predicted that N, P and phytoplankton are abundant in the tail water discharge area, and potential water purification could be achieved by cultivating $H$. cumingii in this area. Meanwhile, this "fish and mussel mixed breeding mode" can realize the regional division of $H$. cumingii and fish, and promote the more standardized production management in recirculating aquaculture system (Masser et al., 1999).

$H$. cumingii is mainly distributed in large lakes and rivers in east China and plays an important role in the fishery economy and aquatic ecosystem as a result of its value of ecological purification, edibility and pearl cultivation. However, despite the great development in the research of artificial propagation ( $\mathrm{Li}$ and $\mathrm{Li}, 2009)$, genetic breeding (Bai et al., 2016), growth traits and pearl cultivation (Jin et al., 2012), the applied research on $H$. cumingii ecological function and environmental suitability still needs to be improved. Therefore, the main purpose of the investigation is to evaluate the adaptability to the local climate and the purification function of $H$. cumingii before popularized in the recirculating aquaculture system in the Chongqing region, southwestern China. Our results showed that $H$. cumingii adapted to the seasonal changes of water temperature, dissolved oxygen, $\mathrm{pH}$ and other water-chemistry factor in all the sampling sites. In addition to the influence of water environment factors (Lin et al., 2004), the growth and fertility of bivalve shellfish were also affected by the ratio of male to female (Zhao et al., 2013), different sized mussel (Davenport et al., 2011), phytoplankton composition (Vanderploeg et al., 1996), season variation (Naddafi et al., 2007) and fish-shellfish mixed breeding mode (Wang et al., 2018), such as the integrating culture of the mussel with herbivorous or omnivorous fish species in commercial farming (Wang et al., 2009).

At present, there are few studies on the ecological functions of $H$. cumingii, such as the influence on phytoplankton composition. Studies have shown that filter-feeding H. cumingii may potentially support submerged macrophyte growth by reducing cyanobacterial density, but bivalve communities in many lakes and rivers are in decline as a result of overharvesting (He et al., 2014). The present results also revealed that $H$. cumingii could effectively reduce the phytoplankton biomass. The measured value in the shellfish purification area and ecological purification area are generally lower than that of the tail water discharge area in recirculating aquaculture systems. However, the phytoplankton community structure and the total number of dominant algae have no visible change under lower $H$. cumingii stocking density. And more than $65 \%$ of them belong to the Chlorophyta, Cyanophyta and Bacillariophyta phyla, the primary food sources of bivalve shellfish (Marroni et al., 2014). Although there was no discernible effect on phytoplankton community structure and dominant algae in the present $H$. cumingii stocking density, the phytoplankton biomass could be significantly reduced. Therefore, the use of $H$. cumingii has been proposed as an alternative mean to control algal bloom in eutrophic water bodies in recent years (Liu et al., 2014).

This investigation revealed the potential role of $H$. cumingii in water purification, including increasing water transparency, decreasing electro conductivity, ammonia nitrogen and phosphate. Other results of different biological units show that $H$. cumingii can effectively enhance the contaminant removal rates from the ecological floating bed containing aquatic plant (Ipomoea aquatica), aquatic animal (H. cumingii), artificial medium (Wang et al., 2015). Furthermore, this purification of $H$. cumingii unit on nitrogen, phosphorus and COD was much lower than that of the aquatic plants unit and 
microorganisms unit. These results suggest that the filter feeding of $H$. cumingii promotes the solubilization and mineralization of particulate organic matters, and improves the purification efficiency of the floating bed by microorganism purification (Wang et al., 2015). Therefore, the environmental response mechanism and interaction between $H$. cumingii and other aquatic organisms are worthy for further study.

\section{Conclusion}

Overall, the results of the annual investigation show that there is plenty of phytoplankton bait in the water environment in southwest China, and the seasonal variation range of physical and chemical indices completely meets the growth demand for $H$. cumingii. Meanwhile, the results also indicate that $H$. cumingii is an excellent way for algal bloom controlling and water quality regulating in the recirculating aquaculture system and the mixed farming model based on the recirculating aquaculture system is worthy for further study.

Acknowledgements. This research was supported by "Fundamental Research Funds for the Central Universities, Ministry of Education, China (SWU117047)", "Chongqing Municipal Social Livelihood Project (cstc2018jscx-msybX0235)" and "National Shellfish Industry Technology System Project, Ministry of Finance, China (CARS-49)". The authors thank the five testing sites for facilitating in the investigation. And we also thank the group members in Research Center of Fishery Resources and Environment for providing assistance.

\section{REFERENCES}

[1] Bai, Z. Y., Han, X. K., Liu, X. J., Li, Q. Q., Li, J. L. (2016): Construction of a high-density genetic map and QTL mapping for pearl quality-related traits in Hyriopsis cumingii. Scientific Reports 32608.

[2] Bianchi, V. A., Castro, J. M., Rocchetta, I., Bieczynski, F., Luquet, C. M. (2014): Health status and bioremediation capacity of wild freshwater mussels (Diplodon chilensis) exposed to sewage water pollution in a glacial Patagonian lake. - Fish \& shellfish Immunology 37(2): 268-277.

[3] Brune, D. E., John, A. C., Schwedler, T. E. (2001): Partitioned aquaculture system. - US Patent. No. 6,192,833.

[4] Cha, Y. K., Stow, C. A., Nalepa, T. F., Reckhow, K. H. (2011): Do invasive mussels restrict offshore phosphorus transport in Lake Huron? - Environmental Science \& Technology 45: 7226-7231.

[5] Daines, S. J., Clark, J. R., Lenton, T. M. (2014): Multiple environmental controls on phytoplankton growth strategies determine adaptive responses of the N: P ratio. - Ecology Letters 17(4): 414-425.

[6] Dan, H., Ruobo, G. (2002): Freshwater pearl culture and production in China. Aquaculture Asia 7(1): 6-8.

[7] Davenport, J., Ezgeta-Balić, D., Peharda, M., Skejić, S., Ninčević-Gladan, Ž., Matijević, S. (2011): Size-differential feeding in Pinna nobilis L. (Mollusca: Bivalvia): exploitation of detritus, phytoplankton and zooplankton. - Estuarine Coastal and Shelf Science 92(2): 246-254.

[8] Ebeling, J. M., Timmons, M. B., Joiner, J. A., Labatut, R. A. (2005): Mixedcell Raceway: Engineering design criteria, construction, and hydraulic characterization. - North American Journal of Aquaculture 67(3): 193-201. 
[9] Hawkins, A. J. S., Pascoe, P. L., Parry, H., Brinsley, M., Cacciatore, F. (2013): Comparative feeding on chlorophyll-rich versus remaining organic matter in bivalve shellfish. - Journal of Shellfish Research 32(3): 883-898.

[10] He, H., Liu, X., Liu, X., Yu, J., Li, K., Guan, B., Jeppesen, E., Liu, Z. (2014): Effects of cyanobacterial blooms on submerged macrophytes alleviated by the native Chinese bivalve Hyriopsis cumingii: A mesocosm experiment study. - Ecological Engineering 71: 363-367.

[11] Hoellein, T. J., Zarnoch, C. B., Grizzle, R. E. (2015): Eastern oyster (Crassostrea virginica) filtration, biodeposition, and sediment nitrogen cycling at two oyster reefs with contrasting water quality in Great Bay Estuary (New Hampshire, USA). - Biogeochemistry 122(1): 113-129.

[12] Horton, M., Keys, A., Kirkwood, L., Mitchell, F., Kyle, R., Roberts, D. (2015): Sustainable catchment restoration for reintroduction of captive bred freshwater pearl mussels Margaritifera margaritifera. - Limnologica 50: 21-28.

[13] Jin, W., Bai, Z., Fu, L., Zhang, G., Li, J. (2012): Genetic analysis of early growth traits of the triangle shell mussel, Hyriopsis Cumingii, as an insight for potential genetic improvement to pearl quality and yield. - Aquaculture International 20(5): 927-933.

[14] Jin, C., Zhao, J. Y., Liu, X. J., Li, J. L. (2019): Expressions of shell matrix protein genes in the pearl sac and its correlation with pearl weight in the first 6 months of pearl formation in Hyriopsis cumingii. - Marine Biotechnology 21(2): 240-249.

[15] Kellogg, L. M., Cornwell, J. C., Owens, M. S., Paynter, K. T. (2013): Denitrification and nutrient assimilation on a restored oyster reef. - Marine Ecology Progress Series 480: 119.

[16] Kingsford, R. T., Biggs, H., Pollard, S. (2011): Strategic adaptive management in freshwater protected areas and their rivers. - Conservation Biology 16(1): 30-41.

[17] Li, J. L., Li, Y. S. (2009): Aquaculture in China-Freshwater pearl culture. - World Aquaculture 40: 60-62.

[18] Lin, Q. X., Wang, Y., Gao, J. H., Zhu, S. B., Wang, W. L. (2004): Water quality for culturing freshwater pearl mussel, Hyriopsis cumingii in waters scatted in different regions in China. - Journal of shanghai fisheries university 17(3): 327-332. (in Chinese).

[19] Liu, Q. G., Hu, M. H., Wu, Z. (2014): Can mussels change phytoplankton community structure and enhance prawn production in semi-enclosed prawn ponds? - Aquaculture Research 46: 2559-2564.

[20] Liu, Y., Li, L., Zheng, L., Fu, P., Wang, Y., Nguyen, H., Shen, X., Sui, Y. (2020): Antioxidant responses of triangle sail mussel Hyriopsis cumingii exposed to harmful algae Microcystis aeruginosa and high pH. - Chemosphere 243: 125241.

[21] Marroni, S., Iglesias, C., Mazzeo, N., Clemente, J., De Mello, F. T., Pacheco, J. P. (2014): Alternative food sources of native and non-native bivalves in a subtropical eutrophic lake. - Hydrobiologia 735(1): 263-276.

[22] Martins, C. I. M., Eding, E. H., Verdegem, M. C., Heinsbroek, L. T., Schneider, O., Blancheton, J. P., Roqued'Orbcastel, P., Verreth, J. A. J. (2010): New developments in recirculating aquaculture systems in Europe: A perspective on environmental sustainability. - Aquacultural engineering 43(3): 83-93.

[23] Masser, M. P., James, R., Losordo, T. M. (1999): Recirculating aquaculture tank production systems-Management of recirculating systems. - SRAC Publication 452.

[24] Modesto, V., Ilarri, M., Souza, A. T., Lopes-Lima, M., Douda, K., Clavero, M., Sousa, R. (2018): Fish and mussels: Importance of fish for freshwater mussel conservation. - Fish and Fisheries 19: 244-259.

[25] Naddafi, R., Pettersson, K., Eklöv, P. (2007): The effect of seasonal variation in selective feeding by zebra mussels (Dreissena polymorpha) on phytoplankton community composition. - Freshwater Biology 52(5): 823-842.

[26] Qu, X., Xia, W., Wang, R., Zhang, Y., Xie, Z., Trushenski, J., Chen, Y. (2018): Effects of Aquaculture on Lakes in the Central Yangtze River Basin, China, II: Benthic Macroinvertebrates. - North American Journal of Aquaculture 80(4): 369-378. 
[27] Ren, J. S., Ross, A. H., Hayden, B. J. (2006): Comparison of assimilation efficiency on diets of nine phytoplankton species of the greenshell mussel Perna canaliculus. - Journal of shellfish research 25(3): 887-893.

[28] Vanderploeg, H. A., Liebig, J. R., Gluck, A. A. (1996): Evaluation of different phytoplankton for supporting development of zebra mussel larvae (Dreissena polymorpha): the importance of size and polyunsaturated fatty acid content. - Journal of Great Lakes Research 22: 36-45.

[29] Wang, Y., Wang, W. L., Qin, J. G., Wang, X. D., Zhu, S. B. (2009): Effects of integrated combination and quicklime supplementation on growth and pearl yield of freshwater pearl mussel, Hyriopsis cumingii (Lea, 1852). - Aquaculture Research 40(14): 1634-1641.

[30] Wang, G., Wang, X., Wu, L., Li, X. (2015): Contribution and Purification Mechanism of Bio components to Pollutants Removal in an Integrated Ecological Floating Bed. - Journal of Civil, Architectural \& Environmental Engineering 4: 136-141.

[31] Wang, L., Ma, L., Sun, J., Zhang, Y., Zhou, Q., Wu, Z., He, F. (2018): Effects of different aquaculture methods for introduced bivalves (Hyriopsis cumingii) on seston removal and phosphorus balance at the water-sediment interface. - Journal of Freshwater Ecology 33(1): 251-265.

[32] Watten, B. J., Honeyfield, D. C., Schwartz, M. F. (2000): Hydraulic characteristics of a rectangular mixed-cell rearing unit. - Aquacultural engineering 24(1): 59-73.

[33] Wei, F. S., Qi, W. Q., Bi, T., Sun, Z., Huang, Y. (2002): Standard methods for water and wastewater monitoring and analysis. - China Environmental Science Press, Beijing.

[34] Weng, J. Z., Xu, H. S. (2010): The common freshwater phytoplankton algae atlas of China. - Shanghai Science and Technology Press, China 1-225.

[35] Zhang, G., Luo, Y., Zhang, W., Fang, A., Ye, R., Ren, G., Yang, S. (2019): The effect of two selected strains of mussels as donor or host on the color of cultivated pearls. - Journal of Shellfish Research 38(2): 363-369.

[36] Zhang, X. L., Cui, L. F., Li, S. M. (2019): China Fishery Statistical Yearbook 2018. - China Agriculture Press 1-172. (in Chinese).

[37] Zhao, Y., Bai, Z., Fu, L., Liu, Y., Wang, G., Li, J. (2013): Comparison of growth and pearl production in males and females of the freshwater mussel, Hyriopsis cumingii, in China.Aquaculture International 21(6): 1301-1310.

[38] Zhou, X., Zheng, J. (2005): Hydrobiology atlas of Chongqing section of the three gorges reservoir area. - China Environmental Science Press 1-125.

[39] Zieritz, A., Bogan, A. E., Froufe, E., Klishko, O., Kondo, T., Kovitvadhi, U., Kovitvadhi, S., Jin, H. L., Lopes-Lima, M., Pfeiffer, J. M., Sousa, R., Van Do, T., Vikhrev, I., Zanatta, D. T., Sousa, R. (2018): Diversity, biogeography and conservation of freshwater mussels (Bivalvia: Unionida) in East and Southeast Asia. - Hydrobiologia 810(1): 29-44. 